\title{
16. A REVIEW OF DEEP SEA DRILLING PROJECT GEOTHERMAL MEASUREMENTS THROUGH LEG $7^{1}$
}

\author{
R. D. Hyndman, Pacific Geoscience Centre, Earth Physics Branch, Department of Energy, Mines and Resources \\ M. G. Langseth, Lamont Doherty Geological Observatory \\ and \\ R. P. Von Herzen, Department of Geology and Geophysics, Woods Hole Oceanographic Institution ${ }^{2}$
}

\begin{abstract}
The geothermal measurements made from the scientific drilling ship Glomar Challenger to 1981 are evaluated, edited, and reviewed. By 1981, reliable heat-flow measurements had been made in over fifty DSDP drill holes in all of the world oceans except the Arctic. Most temperature measurements were made at sub-bottom depths between 75 and 250 meters, although some data were obtained at depths less than 30 and over 1000 meters. Temperatures were obtained a significant distance into the crust in eight holes. The main general conclusions are as follows:

1) There are no large or systematic differences between drill-hole heat-flow values and oceanographic probe values obtained nearby.

2) There are no clear changes of heat flow with depth in areas with thick sedimentary sections indicative of either long-term bottom-water temperature changes or large heat production in the sediments. Vertical migration of interstitial water is suggested at several sites where the sediment is thin and the temperature gradient high.

3) Temperatures in the crustal parts of deep-sea drill holes exhibit a wide range of behavior generally indicating hydrothermal circulation in the upper crust. At five sites seawater is inferred to be moving down the holes into the crust, indicating sub-hydrostatic formation pressures and very high permeability in the upper crust. In two deep holes, however, such flow is limited to above about 500 meters sub-bottom, and heat fluxes close to theoretical cooling-lithosphere values for the age of the crust ( 6 and $7 \mathrm{Ma}$ ) are found at greater depths. These sites suggest that hydrothermal circulation may be concentrated at very shallow depths in the crust. A summary table is presented of the reliable heat-flow data and an Appendix provides detailed comments on all the measurements attempted.
\end{abstract}

\section{INTRODUCTION}

Geothermal measurements made from the Glomar Challenger during the first five years of the Deep Sea Drilling Project, to Leg 26, were reviewed by Erickson et al. (1975). In this article, we collect and provide a brief review of the measurements in the seven years following, through Leg 71. Since there have been many different observers and numerous techniques employed, we recognize the need for careful editing and evaluation of the measurements on a consistent basis. We provide little site-specific interpretation, since this requires integration with other local data. Our discussion is restricted to the measurement characteristics and to general conclusions about thermal processes in the sediments and the upper ocean crust. The reader is directed to pertinent volumes of the Initial Reports of the Deep Sea Drilling Project for details of the measurements and for the geological settings of the drill holes.

The main impetus for the deep-sea drill-hole geothermal program initially came from the need to establish the validity of numerous seafloor measurements using short probes. Those measurements give temperature and thermal conductivity profiles some 2 to 15 meters into the

\footnotetext{
${ }^{1}$ Hyndman, R. D., Salisbury, M. H., et al., Init. Repts. DSDP, Vol. 78B: Washington (U.S. Govt. Printing Office).

2 Addresses: (Hyndman) Pacific Geoscience Centre, Earth Physics Branch, Department of Energy, Mines, and Resources P.O. Box 6000, Sidney, B.C. V8L 4B2 British Columbia, Canada; (Langseth) Lamont Doherty Geological Observatory, Palisades, NY 10964; (Von Herzen) Department of Geology and Geophysics, Woods Hole Oceanographic Institution, Woods Hole, MA 02543.
}

seafloor, and are therefore susceptible to short-term bottom-temperature variations, to the thermal refraction effects of small-scale bottom topograpy and thermal conductivity contrasts, and to sedimentation and erosion. There was also the hope that drill-hole measurements would permit the great accuracy needed to differentiate among varous thermal models of the lithosphere, particularly in setting constraints on the cooling and aging process.

Those deep-sea drill-hole measurements reviewed by Erickson et al. (1975) did establish the validity of the conventional heat-probe measurements; no systematic differences were found between drill-hole heat flows and conventional measurements made nearby. Also, no significant thermal transients were observed in any of the holes, although the resolution of such transients by downhole temperature measurements was less than had been hoped. The drill-hole measurements also suggested that, in general, the effects of small-scale seafloor topography, conductivity contrasts, migration of sedimentary interstitial water, and other aspects of the seafloor environment are small and do not commonly generate systematic biases. However, the variability among nearby hole measurements seems to be less than among conventional ocean-probe values; this is interpreted to indicate that heat-flow measurements in deep-sea drill holes are less susceptible to the seafloor environmental effects which cause at least some of the variability in conventional oceanic heat-flow data. The various difficulties of measuring both temperature gradient and thermal conductivity 
in drill holes have limited the estimated precision of heat-flow values to about $\pm 10 \%$, which is no better than can be obtained by standard heat-probe measurements, although the accuracy of the estimated true deep heat-flux from drill-hole measurements may be somewhat better.

Since the 1975 review by Erickson et al., considerable additional data bearing on the above questions have been acquired. These data (to Leg 71) are reviewed briefly here. In addition, several new questions have arisen that drill-hole thermal measurements could help to resolve. Of particular interest is fluid flow or migration, both in the sediments and in the upper crust. In a few areas, upward or downward fluid migration in the sediments is suggested, both by chemical measurements of sedimentary pore fluids and by conventional ocean-probe temperature data. Such fluid migration should generally be evident as curvature of deep drill-hole temperature profiles. A number of deep crustal holes have also been drilled, permitting direct study of the thermal regime in the upper crust, in particular the extent and nature of hydrothermal circulation. All the measurements that we consider reliable are given in Table 1 , and their locations are given in Figure 1. Notes on most of the downhole temperature measurements are given in the Appendix.

\section{TEMPERATURE MEASUREMENT TECHNIQUES}

A large thermal disturbance, requiring on the order of ten times the drilling period to decay, is generated by circulation of drilling fluid in DSDP holes. Because a decay period of this magnitude is longer than the ship can remain on site, either (1) the temperatures measured in the hole must be correctly extrapolated to equilibrium, or (2) the temperatures must be measured at intervals during drilling by probes penetrating the undisturbed sediments just below the bottom of the hole. Most of the drill-hole heat-flow measurements in sedimentary sections were made using the second technique, although several important results have been obtained by extrapolating logged drill-hole temperatures to equilibrium (estimates of undisturbed temperatures in crustal drill holes have been obtained only by extrapolation of temperatures measured in the holes).

\section{Downhole Sediment Temperature Probes}

The various bottomhole sediment temperature probes deployed from the Glomar Challenger have been described by Erickson (1973), Erickson et al. (1975), and Yokota et al. (1979) (Figure 2). The instruments consist of self-contained temperaure-recording devices mounted in a core barrel. The core barrel is dropped or lowered down the drill pipe and latched in behind the drill bit, while the bit is held just above the bottom of the hole. A long probe, containing a thermistor temperature sensor, extends through and beyond the bit for several decimeters. The drill string is then lowered to force the probe into the undisturbed sediments below the bottom of the hole. The probe length extending beyond the bit has been kept as long as possible to penetrate to undisturbed sediments, but not so long as to risk bending it around the bit if the drill bit settles. Several heat probes have been lost and drill-pipe trips to the surface required because of such failures. Thick (2.0-2.5 $\mathrm{cm}$ in diameter) probes with thinner (0.6-1.2 $\mathrm{cm}$ in diameter), shorter time-constant tips, the total extending some $60 \mathrm{~cm}$ beyond the bit, have generally been used to minimize this problem. For Sites 453 to 493, however, a large-diameter probe without a smaller-diameter tip was used; the time constant was thus longer and the extrapolation less accurate. Measurements have been possible only at intermediate depths where the sediment is sufficiently consolidated to support the bit and probe motionless during measurement, but soft enough to permit penetration of the probe. There have been very few successful measurements at depths less than 50 meters sub-bottom, and most have been made below 75 meters sub-bottom. Several successful measurements have been made below $\mathbf{4 0 0}$ meters sub-bottom, but probe penetration is generally not possible below 250 meters. Deep-sea oozes permit only a particularly small measurement-depth interval. A serious effort was made initially to design an instrument that would be latched firmly enough into the bit assembly to permit it to penetrate into the bottom sediments, then be released and forced up into the core barrel at the start of coring. Combining temperature measurements and coring would have saved considerable time, but was generally unsuccessful; the latch either released prematurely, so that unreliable temperatures were recorded, or did not release at all, so that no core was obtained. The technique has not been attempted since Leg 26 . The possibility of temperature measurement concurrent with sediment sampling has been revived with a new instrument designed by R. P. Von Herzen and now being tested. It has a temperature sensor and a miniature recording unit embedded in the tip of the hydraulic piston corer used with the Glomar Challenger drill string.

Experience evaluating the validity of individual temperature measurements has come gradually. We now conclude that only sediment temperature measurements with time-temperature records exhibiting the characteristic probe-penetration heating and subsequent decay (Figure 3) are certain to be reliable. As already indicated, good measurements can be obtained only at depths where the sediments are strong enough to support the weight of the bit, yet weak enough to allow penetration. If the sediments are sufficiently consolidated to support the bit assembly, they usually generate significant heating on probe penetration. The thermal response of a cylindrical probe to a pulse heating or cooling is given by the $F(\alpha, \tau)$ function described by Bullard (1954) and Jaeger (1956). It approaches a $1 / t$ function at long times (Figure 3). The smaller-diameter probes have a thermal time constant of about two minutes, and require at least five, and ideally twenty, minutes undisturbed in the bottom to permit extrapolation to equilibrium temperature. The large-diameter probe used for a few measurements has a much longer time constant (15-30 min.). The observation period required for accurate extrapolation with a given precision is longer if the amplitude of the initial disturbance is high. In a few cases where the hole-bottom temperature is high and the sediment is soft, the penetration heating is not sufficient to raise the small-diameter probe to the sediment temperature, and the approach to equilibrium is a warming. Almost all of the large-diameter probe penetrations exhibited a warming approach to equilibrium. The time-temperature plot still follows the cylindrical-probe decay function, although representative of a negative thermal pulse (Figure 3B).

The theoretical decay curves assume an instantaneous heating of the probe at $t=0 \mathrm{~min}$. However, a finite time is required for a sediment probe to reach its peak temperature (see, e.g., Hyndman et al., 1979). As a consequence, the effective origin time of the instantaneous pulse is delayed, the amount of delay depending on the probe's diameter and internal thermal properties. Matching of actual records with the $F(\alpha, \tau)$ functions indicates a delay in the effective origin time of up to $1 \mathrm{~min}$. from the time of the first temperature change for the $1.2-\mathrm{cm}-$ (1/2-inch-) diameter probes used for recent measurements in the DSDP program.

A minority of the measurements attempted in DSDP holes exhibit temperature histories that conform to the theoretically expected equilibrium curve. Most of the records show a pronounced deviation from the ideal decay curves within two minutes of penetration. The reasons for these deviations are numerous and difficult to diagnose from the temperture records alone. Among the causes of poor data are the following:

1) Continued motion of the bit and probe in the sediments (as from slow settling), which leads to further heating of the probe; or penetration of colder drill-hole water to the probe end.

2) Insufficient penetration, which makes the probe vulnerable to hole-bottom disturbances only a very short time after penetration.

3) Filling of the bottom of the hole by cuttings and sediments slumped from the hole's walls. This material is usually mixed with colder drilling fluids and, if not completely penetrated by the probe, will cause the probe to register anomalously low temperatures.

In this data summary we have included only sediment-probe heatflow values having (1) at least one measurement point where the timetemperature behavior is, for at least a short time, that for a pulse heating or cooling of a cylindrical probe; and (2) a good bottom-water temperature estimate. Some potentially good data have thus been excluded, but we feel that these are necessary criteria to establish the validity of a hole-bottom temperature-probe measurement. A few mea- 
Table 1. DSDP Heat flow data.

\begin{tabular}{|c|c|c|c|c|c|c|c|c|c|c|c|}
\hline Hole & Latitude & Longitude & $\begin{array}{l}\text { Water } \\
\text { depth } \\
\text { (m) }\end{array}$ & $\begin{array}{l}\text { Sub- } \\
\text { bottom } \\
\text { depth } \\
\text { (m) }\end{array}$ & Geographic area & Probes & $\begin{array}{l}\text { Temperature } \\
\text { gradient } \\
\left(\mathrm{m}^{\circ} \mathrm{C} \mathrm{m}^{-1}\right)\end{array}$ & $\begin{array}{c}\text { Thermal } \\
\text { conductivity } \\
\left(\mathrm{W} \mathrm{m}^{-1} \mathrm{~K}^{-1} \text { ) }\right.\end{array}$ & $\begin{array}{c}\text { Heat } \\
\text { flow } \\
\left(\mathrm{mW} \mathrm{m}^{-2}\right)\end{array}$ & Quality $^{\mathrm{a}}$ & Reference \\
\hline 206 & $32^{\circ} 01^{\prime} \mathrm{S}$ & $165^{\circ} 27^{\prime} \mathrm{E}$ & 3196 & 174 & $\begin{array}{l}\text { New Caledonia Basin } \\
\text { (W. Pacific) }\end{array}$ & 3 & 50 & 1.2 & 59 & Fair & Von Herzen, 1973 \\
\hline 214 & $11^{\circ} 20^{\prime} \mathrm{S}$ & $88^{\circ} 43^{\prime} \mathrm{E}$ & 1655 & 228 & $\begin{array}{l}90 \text { East Ridge (Indian } \\
\text { Ocean) }\end{array}$ & 3 & 50 & 1.2 & 61 & Good & Sclater and Erickson, 1974 \\
\hline 217 & $08^{\circ} 56^{\prime} \mathrm{N}$ & $90^{\circ} 32^{\prime} \mathrm{E}$ & 3010 & 135 & $\begin{array}{l}\text { Bay of Bengal (Indian } \\
\text { Ocean) }\end{array}$ & 2 & 72 & 0.97 & 70 & Good & Sclater and Erickson, 1974 \\
\hline 225 & $21^{\circ} 19^{\prime} \mathrm{N}$ & $38^{\circ} 15^{\prime} \mathrm{E}$ & 1228 & 78 & Red Sea & 2 & 80 & 1.17 & 94 & Fair & Girdler et al., 1974 \\
\hline 227 & $21^{\circ} 20^{\prime} \mathrm{N}$ & $38^{\circ} 08^{\prime} \mathrm{E}$ & 1795 & 159 & Red Sea & 4 & 117 & 1.30 & 152 & Fair & Girdler et al., 1974 \\
\hline 242 & $15^{\circ} 50.7^{\prime} \mathrm{s}$ & $41^{\circ} 49.2^{\prime} \mathrm{E}$ & 2275 & 317 & Indian Ocean & 2 & 27 & 1.09 & 29 & Good & Marshall and Erickson, 1974 \\
\hline 249 & $29^{\circ} 57^{\prime} \mathrm{S}$ & $36^{\circ} 05^{\prime} \mathrm{E}$ & 2088 & 140 & $\begin{array}{l}\text { Mozambique Rise } \\
\text { (Indian Ocean) }\end{array}$ & 1 & 37 & 1.12 & 42 & Good & Marshall and Erickson, 1974 \\
\hline 253 & $24^{\circ} 53^{\prime} \mathrm{N}$ & $87^{\circ} 22^{\prime} \mathrm{E}$ & 1962 & 142 & $\begin{array}{l}90 \text { East Ridge (Indian } \\
\text { Ocean) }\end{array}$ & 3 & 45 & 1.34 & 61 & Excellent & Hyndman et al., 1974 \\
\hline 254 & $30^{\circ} 58^{\prime} \mathrm{S}$ & $87^{\circ} 54^{\prime} \mathrm{E}$ & 1253 & 176 & $\begin{array}{l}90 \text { East Ridge (Indian } \\
\text { Ocean) }\end{array}$ & 3 & 48 & 1.15 & 55 & Excellent & Hyndman et al., 1974 \\
\hline 256 & $23^{\circ} 28^{\prime} \mathrm{S}$ & $100^{\circ} 46^{\prime} \mathrm{E}$ & 5361 & & Indian Ocean & 1 & 54 & 0.85 & 46 & Fair & Hyndman et al., 1974 \\
\hline 257 & $30^{\circ} 59^{\prime} \mathrm{S}$ & $108^{\circ} 21^{\prime} \mathrm{E}$ & 5278 & 133 & $\begin{array}{l}\text { Perth Basin (Indian } \\
\text { Ocean) }\end{array}$ & $i$ & 70 & 0.82 & 58 & Fair & Hyndman et al., 1974 \\
\hline 301 & $41^{\circ} 04^{\prime} \mathrm{N}$ & $134^{\circ} 03^{\prime} \mathrm{E}$ & 3520 & 126 & Sea of Japan & 1 & 120 & 0.70 & 85 & Good & Watanabe et al., 1975 \\
\hline $332 \mathrm{~A}$ & $36^{\circ} 52^{\prime} \mathrm{N}$ & $33^{\circ} 38^{\prime} \mathrm{W}$ & 1818 & 83 & Mid-Atlantic Ridge & 1 & 27 & 1.08 & 29 & Good & Hyndman et al., 1976, 1977 \\
\hline 332B & $36^{\circ} 52^{\prime} \mathrm{N}$ & $33^{\circ} 39^{\prime} \mathrm{W}$ & 1806 & 541 & $\begin{array}{l}\text { Mid-Atlantic Ridge } \\
\text { (crust) }\end{array}$ & $1+\log$ & 21 & 1.08 & 23 & Excellent & Hyndman et al., 1976, 1977 \\
\hline 334 & $37^{\circ} 02^{\prime} \mathrm{N}$ & $34^{\circ} 25^{\prime} \mathrm{W}$ & 2632 & 342 & $\begin{array}{l}\text { Mid-Atlantic Ridge } \\
\text { (crust) }\end{array}$ & $1+\log$ & 42 & 1.08 & 45 & Good & Hyndman et al., 1976, 1977 \\
\hline 335 & $37^{\circ} 18^{\prime} \mathrm{N}$ & $35^{\circ} 12^{\prime} \mathrm{W}$ & 3198 & 324 & $\begin{array}{l}\text { Mid-Atlantic Ridge } \\
\text { (crust) }\end{array}$ & $3+\log$ & 16 & 1.26 & 21 & Excellent & Hyndman et al., 1976, 1977 \\
\hline $372 \mathrm{~A}$ & $40^{\circ} 02^{\prime} \mathrm{N}$ & $04^{\circ} 48^{\prime} \mathrm{E}$ & 2699 & 155 & $\begin{array}{l}\text { E. of Menorca (Medi- } \\
\text { terranean Sea) }\end{array}$ & 4 & 76 & 1.35 & 103 & Excellent & $\begin{array}{l}\text { Erickson and Von Herzen, } \\
1978 \mathrm{a}\end{array}$ \\
\hline $373 \mathrm{~A}$ & $39^{\circ} 44^{\prime} \mathrm{N}$ & $13^{\circ} 00^{\prime} \mathrm{E}$ & 3517 & 125 & $\begin{array}{l}\text { Tyrrhenian Sea (Medi- } \\
\text { terranean Sea) }\end{array}$ & 2 & 79 & 0.91 & 72 & Good & $\begin{array}{l}\text { Erickson and Von Herzen, } \\
1978 \mathrm{a}\end{array}$ \\
\hline 374 & $35^{\circ} 51^{\prime} \mathrm{N}$ & $18^{\circ} 12^{\prime} \mathrm{E}$ & 4078 & 304 & $\begin{array}{l}\text { Messinian Abyssal Plain } \\
\text { (Mediterranean Sea) }\end{array}$ & 5 & 28 & 1.20 & 34 & Excellent & $\begin{array}{l}\text { Erickson and Von Herzen, } \\
1978 \mathrm{a}\end{array}$ \\
\hline 376 & $34^{\circ} 52^{\prime} \mathrm{N}$ & $31^{\circ} 48^{\prime} \mathrm{E}$ & 2101 & 103 & $\begin{array}{l}\text { W. of Cyprus (Mediter- } \\
\text { ranean Sea) }\end{array}$ & 2 & 26 & 1.17 & 31 & Good & $\begin{array}{l}\text { Erickson and Von Herzen, } \\
1978 \mathrm{a}\end{array}$ \\
\hline $378 / 378 \mathrm{~A}$ & $35^{\circ} 57^{\prime} \mathrm{N}$ & $25^{\circ} 07^{\prime} \mathrm{E}$ & 1835 & 303 & $\begin{array}{l}\text { N. of Crete (Mediterra- } \\
\text { nean Sea) }\end{array}$ & 2 & 77 & 1.16 & 89 & Excellent & $\begin{array}{l}\text { Erickson and Von Herzen, } \\
1978 \mathrm{a}\end{array}$ \\
\hline 379 & $43^{\circ} 00.3^{\prime} \mathrm{N}$ & $36^{\circ} 00.7^{\prime} \mathrm{E}$ & 2171 & 425 & Black Sea & 5 & 35 & 1.16 & 41 & Excellent & $\begin{array}{l}\text { Erickson and Von Herzen, } \\
1978 \mathrm{~b}\end{array}$ \\
\hline 380 & $42^{\circ} 06.0^{\prime} \mathrm{N}$ & $29^{\circ} 36.9^{\prime} \mathrm{E}$ & 2115 & 370 & Black Sea & 5 & 38 & 1.08 & 41 & Excellent & $\begin{array}{l}\text { Erickson and Von Herzen, } \\
1978 \mathrm{~b}\end{array}$ \\
\hline 381 & $41^{\circ} 40.2^{\prime} \mathrm{N}$ & $29^{\circ} 25.0^{\prime} \mathrm{E}$ & 1750 & 180 & Black Sea & 1 & 51 & 0.97 & 43 & Good & $\begin{array}{l}\text { Erickson and Von Herzen, } \\
1978 \mathrm{~b}\end{array}$ \\
\hline 395A & $22^{\circ} 45.3^{\prime} \mathrm{N}$ & $46^{\circ} 04.9^{\prime} \mathrm{E}$ & 4483 & 609 & $\begin{array}{l}\text { Mid-Atlantic Ridge } \\
\text { (crust) }\end{array}$ & $1+\log$ & & (see text) & 180 & Good & Becker et al., this volume \\
\hline 396B & $22^{\circ} 59.1^{\prime} \mathrm{N}$ & $43^{\circ} 30.9^{\prime} \mathrm{W}$ & 4465 & 150 & $\begin{array}{l}\text { Mid-Atlantic Ridge } \\
\text { (crust) }\end{array}$ & 1 & 18 & 1.27 & 23 & Good & $\begin{array}{l}\text { Erickson and Hyndman, } \\
1978\end{array}$ \\
\hline $397 / 397$ A & $26^{\circ} 50.7^{\prime} \mathrm{N}$ & $15^{\circ} 10.8^{\prime} \mathrm{W}$ & 2900 & 448 & $\begin{array}{l}\text { North African Margin } \\
\text { (N. Atlantic) }\end{array}$ & 2 & 42 & 1.40 & 59 & Good & von Rad, Ryan, et al., 1979 \\
\hline 402 & $47^{\circ} 52.5^{\prime} \mathrm{N}$ & $08^{\circ} 50.4^{\prime} \mathrm{W}$ & 2340 & 165 & $\begin{array}{l}\text { Cont. slop W. of Britta- } \\
\text { ny (N. Atlantic) }\end{array}$ & 2 & 37 & 1.24 & 46 & Good & Erickson et al., 1979 \\
\hline 403 & $56^{\circ} 08.3^{\prime} \mathrm{N}$ & $23^{\circ} 17.6^{\prime} \mathrm{W}$ & 2301 & 242 & $\begin{array}{l}\text { Rockall Bank (N. } \\
\text { Atlantic) }\end{array}$ & 4 & 54 & 1.24 & 67 & Excellent & Erickson et al., 1979 \\
\hline 406 & $55^{\circ} 15.5^{\prime} \mathrm{N}$ & $22^{\circ} 05.4^{\prime} \mathrm{W}$ & 2907 & 223 & $\begin{array}{l}\text { Rockall Bank (N. } \\
\text { Atlantic) }\end{array}$ & 3 & 59 & 1.26 & 74 & Excellent & Erickson et al., 1979 \\
\hline 407 & $63^{\circ} 56.3^{\prime} \mathrm{N}$ & $30^{\circ} 34.6^{\prime} \mathrm{W}$ & 2472 & 281 & N. Atlantic & 2 & 64 & 0.91 & 58 & Good & $\begin{array}{l}\text { Luyendyk, Cann, et al., } \\
1979\end{array}$ \\
\hline 438A & $40^{\circ} 37.8^{\prime} \mathrm{N}$ & $143^{\circ} 14.2^{\prime} \mathrm{E}$ & 1558 & 860 & Japan Trench & $\log$ & 32 & 0.88 & 23 & Good & $\begin{array}{l}\text { Langseth and Burch, 1980; } \\
\text { Burch and Langseth, } \\
1981\end{array}$ \\
\hline 439 & $40^{\circ} 37.6^{\prime} \mathrm{N}$ & $143^{\circ} 18.6^{\prime} \mathrm{W}$ & 1656 & 940 & Japan Trench & $\log$ & 36 & 0.89 & 32 & Good & $\begin{array}{l}\text { Langseth and Burch, 1980; } \\
\text { Burch and Langseth, } \\
\text { 1981 }\end{array}$ \\
\hline $440 B$ & $39^{\circ} 44.1^{\prime} \mathrm{N}$ & $143^{\circ} 55.7^{\prime} \mathrm{E}$ & 4509 & 495 & Japan Trench & $\log$ & 24 & 0.94 & 23 & Good & $\begin{array}{l}\text { Langseth and Burch, 1980; } \\
\text { Burch and Langseth, } \\
1981\end{array}$ \\
\hline 453 & $17^{\circ} 54.4^{\prime} \mathrm{N}$ & $143^{\circ} 41.0^{\prime} \mathrm{E}$ & 4693 & 76 & $\begin{array}{l}\text { Mariana Trough (W. } \\
\text { Pacific) }\end{array}$ & 1 & 135 & 0.76 & 103 & Fair & Uyeda and Horai, 1982 \\
\hline 459B & $17^{\circ} 51.8^{\prime} \mathrm{N}$ & $147^{\circ} 18.1^{\prime} \mathrm{E}$ & 4121 & 565 & $\begin{array}{l}\text { Mariana Trough (W. } \\
\text { Pacific) }\end{array}$ & $\log$ & 32 & 0.94 & 30 & Fair & Uyeda and Horai, 1982 \\
\hline $462 A$ & $7^{\circ} 14.3^{\prime} \mathrm{N}$ & $165^{\circ} 01.8^{\prime} \mathrm{E}$ & 5181 & 219 & $\begin{array}{l}\text { Nauru Basin (W. } \\
\text { Pacific) }\end{array}$ & 3 & 49 & 1.01 & 49 & Good & Boyce, 1981 \\
\hline 465 & $33^{\circ} 49.2^{\prime} \mathrm{N}$ & $178^{\circ} 55.1^{\prime} \mathrm{W}$ & 2161 & 86 & Hess Rise (W. Pacific) & 1 & 45 & 1.39 & 62 & Fair & Fujii, 1981 \\
\hline 471 & $23^{\circ} 28.9^{\prime} \mathrm{N}$ & $112^{\circ} 29.8^{\prime} \mathrm{W}$ & 3101 & 95 & W. Pacific & $i$ & 120 & 1.04 & 125 & Fair & Yeats, Haq, et al., 1981 \\
\hline 472 & $23^{\circ} 00.4^{\prime} \mathrm{N}$ & $113^{\circ} 59.7^{\prime} \mathrm{W}$ & 3831 & 88 & W. Pacific & 1 & 141 & 0.79 & 112 & Fair & Yeats, Haq, et al., 1981 \\
\hline 473 & $20^{\circ} 57.9^{\prime} \mathrm{N}$ & $107^{\circ} 03.8^{\prime} \mathrm{W}$ & 3249 & 219 & W. Pacific & 2 & 195 & 0.87 & 170 & Fair & Yeats, Haq, et al., 1981 \\
\hline 475 & $23^{\circ} 03.0^{\prime} \mathrm{N}$ & $109^{\circ} 03.2^{\prime} \mathrm{W}$ & 2631 & 149 & S. of Baja Calif. & 1 & 156 & 1.09 & 170 & Fair & Curray, Moore, et al., 1982 \\
\hline 476 & $23^{\circ} 04.2^{\prime} \mathrm{N}$ & $109^{\circ} 05.4^{\prime} \mathrm{W}$ & 2403 & 123 & S. of Baja Calif. & i & 111 & 0.98 & 108 & Fair & Curray, Moore, et al., 1982 \\
\hline 477 & $27^{\circ} 01.8^{\prime} \mathrm{N}$ & $111^{\circ} 24.0^{\prime} \mathrm{W}$ & 2003 & 48 & Gulf of Calif. & 1 & 962 & 0.88 & 844 & Fair & Curray, Moore, et al., 1982 \\
\hline 479 & $27^{\circ} 50.8^{\prime} \mathrm{N}$ & $111^{\circ} 37.5^{\prime} \mathrm{W}$ & 747 & 231 & $\begin{array}{l}\text { E. Pacific, } 0.5 \mathrm{Ma} \\
\text { (Gulf of California) }\end{array}$ & 3 & 100 & 0.94 & 94 & Good & Curray, Moore, et al., 1982 \\
\hline $482 \mathrm{C}$ & $22^{\circ} 47.4^{\prime} \mathrm{N}$ & $107^{\circ} 59.6^{\prime} \mathrm{W}$ & 2998 & 120 & E. Pacific Rise, $0.5 \mathrm{Ma}$ & 3 & 630 & 0.84 & 529 & Good & $\begin{array}{l}\text { Lewis, 1983; Duennebier, } \\
\text { et al., } 1983\end{array}$ \\
\hline $483 \mathrm{C}$ & $23^{\circ} 53.0^{\prime} \mathrm{N}$ & $108^{\circ} 44.9^{\prime} \mathrm{W}$ & 3070 & 86 & $\begin{array}{l}\text { Tomayo Fracture Zone } \\
\text { (E. Pacific) (crust) }\end{array}$ & 1 & 255 & 0.80 & 205 & Fair & $\begin{array}{l}\text { Lewis, 1983; Duennebier, } \\
\text { et al., } 1983\end{array}$ \\
\hline 493B & $16^{\circ} 22.9^{\prime} \mathrm{N}$ & $98^{\circ} 55.5^{\prime} \mathrm{W}$ & 645 & 851 & $\begin{array}{l}\text { Mexican Margin (E. } \\
\text { Pacific) }\end{array}$ & Log & \multicolumn{4}{|c|}{ (see Appendix) } & Shipley and Shepard, 1982 \\
\hline 501 & $01^{\circ} 13.6^{\prime} \mathrm{N}$ & $83^{\circ} 44.1^{\prime} \mathrm{W}$ & 3457 & 122 & $\begin{array}{l}\text { Costa Rica Rift (E. } \\
\text { Pacific) }\end{array}$ & 1 & 243 & 0.80 & 194 & Good & $\begin{array}{l}\text { Becker, Langseth, and Von } \\
\text { Herzen, 1983; Becker, } \\
\text { Langseth, Von Herzen, } \\
\text { and Anderson, } 1983\end{array}$ \\
\hline
\end{tabular}


Table 1. (Continued).

\begin{tabular}{|c|c|c|c|c|c|c|c|c|c|c|c|}
\hline Hole & Latitude & Longitude & $\begin{array}{l}\text { Water } \\
\text { depth } \\
(\mathrm{m})\end{array}$ & $\begin{array}{l}\text { Sub- } \\
\text { bottom } \\
\text { depth } \\
\text { (m) }\end{array}$ & Geographic area & Probes & $\begin{array}{c}\text { Temperature } \\
\text { gradient } \\
\left(\mathrm{m}^{\circ} \mathrm{C} \mathrm{m}^{-1}\right)\end{array}$ & $\begin{array}{l}\text { Thermal } \\
\text { conductivity } \\
\text { (W } \mathrm{m}^{-1} \mathrm{~K}^{-1} \text { ) }\end{array}$ & $\begin{array}{c}\begin{array}{c}\text { Heat } \\
\text { flow } \\
\left(\mathrm{mW} \mathrm{m}^{-2}\right)\end{array}\end{array}$ & Quality $^{\mathrm{a}}$ & Reference \\
\hline $504 \mathrm{~A}$ & $00^{\circ} 13.6^{\prime} \mathrm{N}$ & $83^{\circ} 43.9^{\prime} \mathrm{W}$ & 3460 & 265 & Costa Rica Rift & $2+\log$ & 179 & 1.23 & 219 & Excellent & $\begin{array}{l}\text { Becker, Langseth, and Von } \\
\text { Herzen, 1983; Becker, } \\
\text { Langseth, Von Herzen, } \\
\text { and Anderson, } 1983\end{array}$ \\
\hline 504B & $01^{\circ} 13.6^{\prime} \mathrm{N}$ & $83^{\circ} 43.9^{\prime} \mathrm{W}$ & 3460 & 1287 & $\begin{array}{l}\text { Costa Rica Rift } \\
\text { (crust-bottom part) }\end{array}$ & Logs & $114-118$ & $1.67-2.05$ & 190 & Excellent & $\begin{array}{l}\text { Becker, Langseth, and Von } \\
\text { Herzen, 1983; Becker, } \\
\text { Langseth, Von Herzen, } \\
\text { and Anderson, } 1983\end{array}$ \\
\hline $504 C$ & $01^{\circ} 13.6^{\prime} \mathrm{N}$ & $83^{\circ} 43.9^{\prime} \mathrm{W}$ & 3460 & 220 & Costa Rica Rift & 3 & 214 & 0.90 & 193 & Excellent & $\begin{array}{l}\text { Becker, Langseth, and Von } \\
\text { Herzen, 1983; Becker, } \\
\text { Langseth, Von Herzen, } \\
\text { and Anderson, } 1983\end{array}$ \\
\hline 505 & $01^{\circ} 54.8^{\prime} \mathrm{N}$ & $83^{\circ} 47.4^{\prime} \mathrm{W}$ & 3537 & 210 & Costa Rica Rift & 4 & 28 & 0.74 & 21 & Good & $\begin{array}{l}\text { Becker, Langseth, and Von } \\
\text { Herzen, 1983; Becker, } \\
\text { Langseth, Von Herzen, } \\
\text { and Anderson, } 1983\end{array}$ \\
\hline 506E,F & $00^{\circ} 36.6^{\prime} \mathrm{N}$ & $86^{\circ} 05.5^{\prime} \mathrm{W}$ & 2711 & variable & $\begin{array}{l}\text { Galapagos Spread Cent. } \\
\text { (E. Pacific) }\end{array}$ & & & (see Appendix) & $570-620$ & Fair & $\begin{array}{l}\text { Becker, Von Herzen, and } \\
\text { Karato, 1983; Becker and } \\
\text { Von Herzen, } 1983\end{array}$ \\
\hline 507A,E,G,1 & $00^{\circ} 34.0^{\prime} \mathrm{N}$ & $86^{\circ} 05.4^{\prime} \mathrm{W}$ & 2712 & variable & Special experiments to & & & (see Appendix) & $374-436$ & Fair & $\begin{array}{l}\text { Becker, Von Herzen, and } \\
\text { Karato, 1983; Becker and } \\
\text { Von Herzen, 1983. }\end{array}$ \\
\hline 508A,D,E & $00^{\circ} 32.0^{\prime} \mathrm{N}$ & $86^{\circ} 06.0^{\prime} \mathrm{W}$ & 2783 & variable & $\begin{array}{l}\text { measure gradients } \\
\text { and conductivities in } \\
\text { mounds area. }\end{array}$ & & & (see Appendix) & $177-228$ & Fair & $\begin{array}{l}\text { Becker, Von Herzen, and } \\
\text { Karato, 1983; Becker and } \\
\text { Von Herzen, } 1983\end{array}$ \\
\hline 509C,D, & $00^{\circ} 35.3^{\prime} \mathrm{N}$ & $86^{\circ} 07.9^{\prime} \mathrm{W}$ & 2677 & variable & & & & (see Appendix) & $509-532$ & Fair & $\begin{array}{l}\text { Becker, Von Herzen, and } \\
\text { Karato, 1983; Becker and } \\
\text { Von Herzen, 1983. }\end{array}$ \\
\hline 510 & $01^{\circ} 36.8^{\prime} \mathrm{N}$ & $86^{\circ} 24.6^{\prime} \mathrm{W}$ & 2781 & 114 & $\begin{array}{r}\text { Galapagos Spreading } \\
\text { Cent. (E. Pacific) }\end{array}$ & 2 & 208 & 0.93 & 193 & Good & $\begin{array}{l}\text { Becker, Von Herzen, and } \\
\text { Karato, 1983; Becker and } \\
\text { Von Herzen, } 1983\end{array}$ \\
\hline 511 & $51^{\circ} 00.3^{\prime} \mathrm{S}$ & $46^{\circ} 58.3^{\prime} \mathrm{W}$ & 2589 & 113 & Falkland Plateau & 2 & 74 & 0.84 & 62 & Excellent & Langseth and Ludwig, 1983 \\
\hline
\end{tabular}

${ }^{a}$ Quality factors are based on the number and quality of temperature points or temperature logs, the quality of the conductivity means, and the reliability of bulk conductivity estimates, particularly in the basement. Excellent: at least two good sediment-temperature points exhibiting thermal pulse decay, or good log plus a good conductivity estimate- better than $10 \%$ uncertainty estimate. Good: at least one good sediment temperature showing thermal decay, or at least two measurements that give a linear gradient, plus a good conductivity estimate-up to $15 \%$ uncertainty estimate. Fair: uncertain temperatures or no conductivities measured, up to $20 \%$ uncertainty estimate, with some possibility of major error in heat-flow result.

surements have been given revised interpretation (see Appendix) where the Initial Reports analysis did not involve an appreciation of the cylindrical probe pulse-decay behavior.

\section{Drill-Hole Temperature Logs}

Four different techniques have been used to obtain temperatures in the hole itself, two using the recording sediment-temperature probe and two using commercial downhole logging tools. In the first technique the drill pipe is lowered to the bottom of the hole and allowed to equilibrate for a short time without circulation, then the temperature vs.- depth record for the hole is obtained by slowly lowering the selfcontained recorder in the pipe (see, e.g., Hyndman et al., 1977). The second technique has the drill string held at a series of depths and the temperature at each depth sensed by the sediment-temperature probe extending a short distance ahead of the bit in the open hole (see, e.g, Becker, Langseth, and Hyndman, this volume). The third technique employs the maximum-reading thermometer included in a number of standard logging tools to obtain the hole-bottom temperature. The final technique uses the commercial high-resolution temperature log (HRT) in the open hole, and is by far the most satisfactory technique if the log can be run in the hole after it has been left undisturbed for some time; but this has been possible in only a few holes.

Temperatures measured in the holes themselves can be extrapolated to equilibrium using a variety of mathematical approximations of the real situation (e.g., Hyndman et al., 1977; Jaeger, 1965; Carslaw and Jaeger, 1959). We note that all of these techniques require knowledge of the hole diameter, which is often highly variable because of drilling washouts, and poorly known. For hole-bottom temperatures, the short circulation-time theory, described by Cooper and Jones (1959) can be used (see, e.g., Von Herzen et al., 1971). For longer circulation times, the most suitable approximation appears to be the formulation of Jaeger $(1956,1961)$ that gives the thermal history after a hole is maintained at a particular temperature, different from its surroundings, for a period of time. A variable, known drill-hole thermal history can be approximated by superposition of a series of constant-temperature periods. Hyndman et al. (1976) assumed that during drilling-circulation the hole was held at a constant temperature equal to the bottom-water temperature. This is valid approximation for large circulation rates, above about 25 1/s (50 strokes per minute of Glomar Challenger's pumps) (see Jaeger, 1961), but the temperture may be significantly higher, paticularly near the bottom of the hole, for smaller circulation rates. Such high circulation rates are normally used in hard formations such as basalt, but much lower rates (i.e., $5 \mathrm{l} / \mathrm{s}$ ) are commonly used to reduce washout in soft formations.

Burch and Langseth (1981) and Langseth and Burch (1980), in a more complete analysis, showed how the disturbance is less for slower circulation rates and how, for such rates, the return to equilibrium could be modeled accurately. First, the hole-wall temperature as a function of time during circulation is estimated using the hole/drill-pipe counterflow heat-exchanger model of Jaeger (1961), and second, the decay with time of the disturbance generated by this thermal history is calculated using the theory of Jaeger (1956) and the superposition theorem. This detailed analysis requires knowledge of the thermal properties of the drill pipe and careful recording of circulation rates throughout the drilling, but promises to be the most satisfactory method of obtaining estimates of undisturbed temperatures (e.g., ten Brink and Langseth, 1982). For all extrapolation techniques, the reliability of drill-hole extrapolations is increased if two or more temperature logs can be run after circulation has stopped, preferably separated by twenty-four hours or more. With temperatures measured at least twice for each depth, an extrapolation technique such as that given by Bullard (1947) can also be used. Recently, Becker, Langseth, and Von Herzen (1983) have developed an extension of this latter technique that takes into account a discontinuous disturbance, using the superposition theorem. An example of drill-hole temperature logs extrapolated to equilibrium is shown in Figure 4.

\section{Thermal Conductivity Measurement}

The thermal conductivities of recovered unconsolidated sediment cores have been measured, either by the transient needle-probe technique (Von Herzen and Maxwell, 1959) or by instruments employing a line heat source and a temperature sensor on the face of a block of insulating material (e.g., the commercial Q.T.M. meter, Showa Denko Inc., Japan-see Horai, 1982-or the instrument designed by V. Vacquier and reported in Carvalho et al., 1980). In both of these instruments the face is placed on the surface of the split core. The values are 


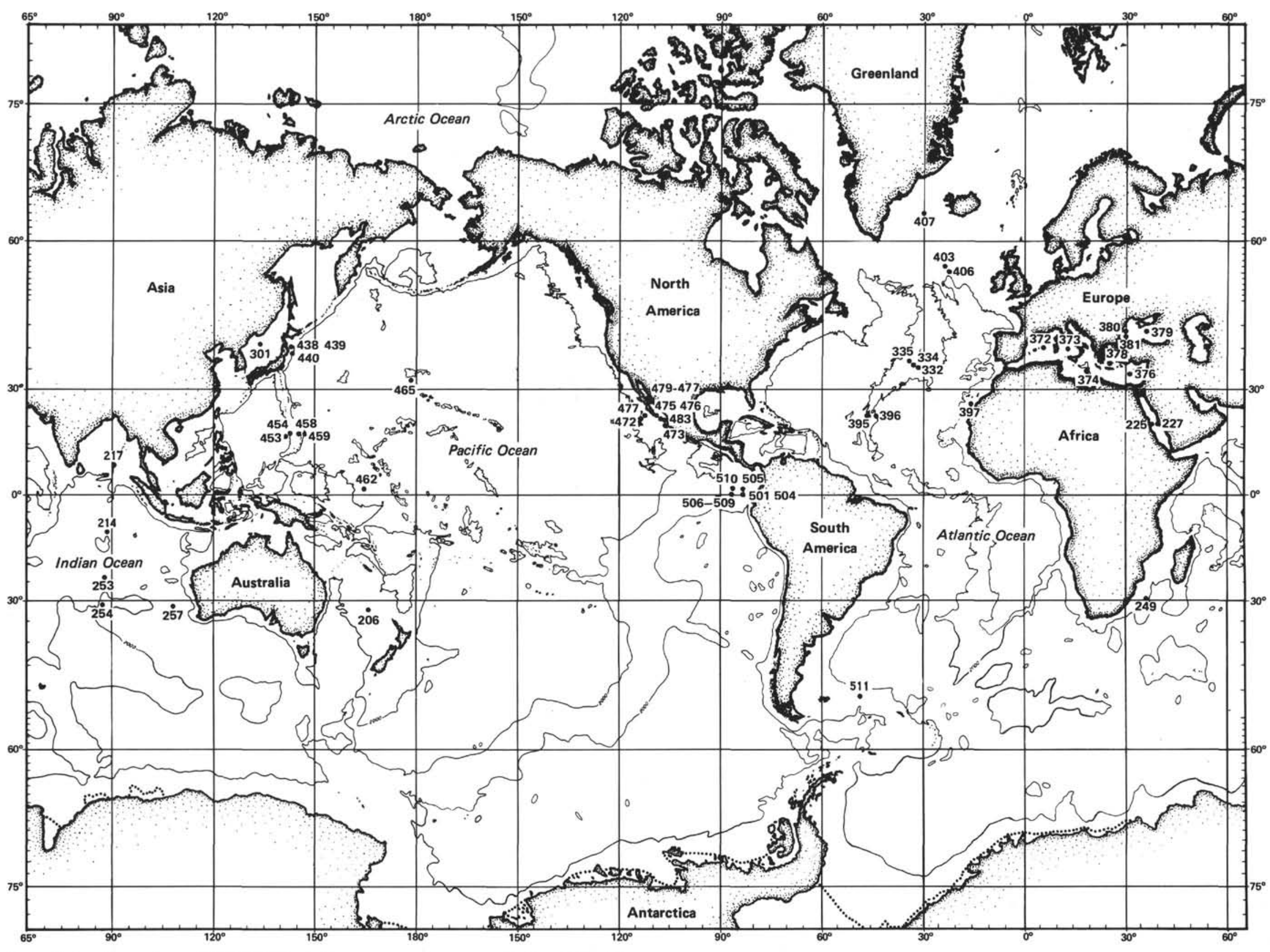




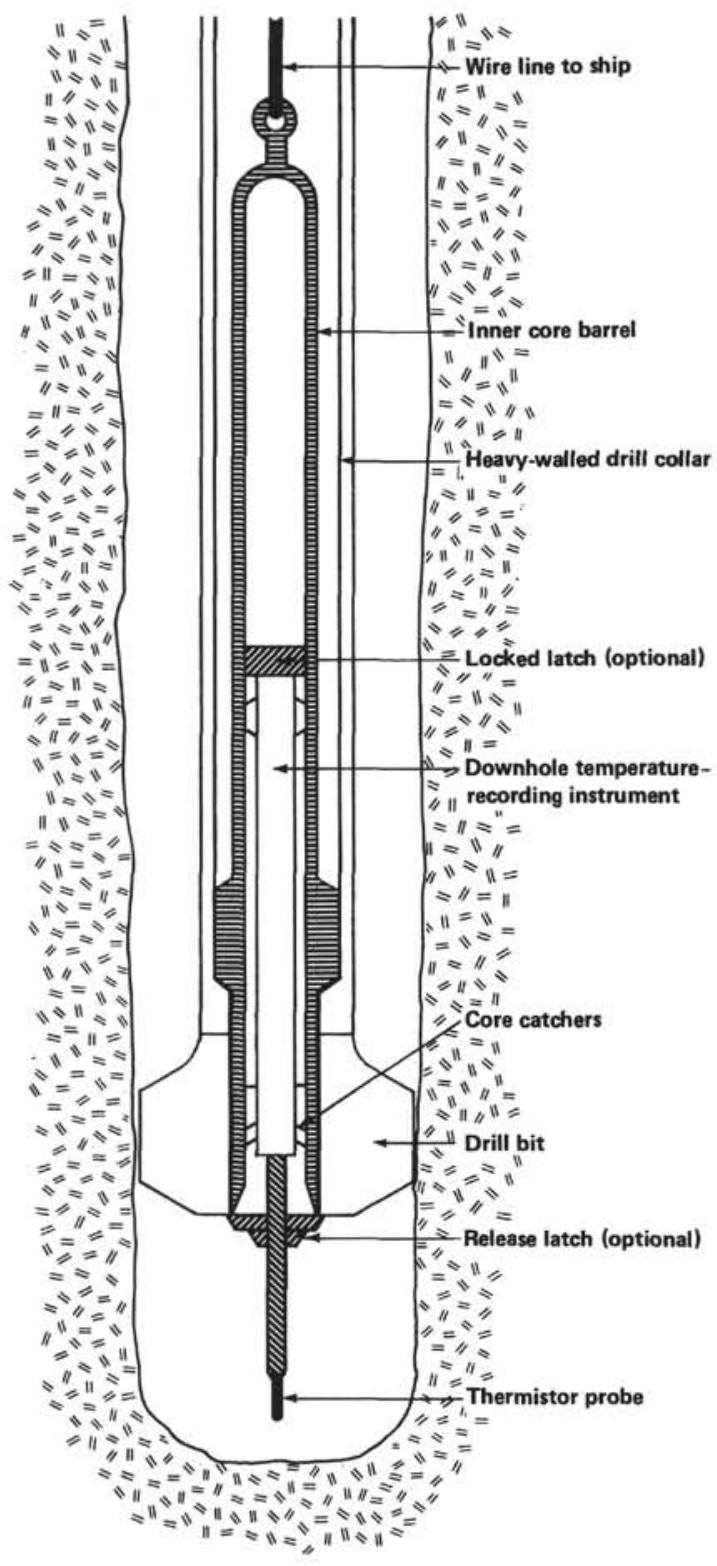

Figure 2. Diagram of the main type of sediment probe used in DSDP (after Erickson et al., 1975).

corrected to seafloor temperatures and pressures, following Ratcliffe (1960). The accuracy of individual conductivity measurements is $\pm 5-$ $10 \%$, depending on the technique used, the sediment type, the degree of coring disturbance, and the care taken in calibration on the individual drilling legs. Also, because of sampling biases, the mean values commonly may represent the section drilled only to within \pm 5 or $10 \%$. The conductivities at several sites have been checked using the porosity-conductivity relations of Ratcliffe (1960), Bullard and Day (1961), and Lachenbruch and Marshall (1966). Since porosities are usually measured on the same cores as the conductivity, these relations provide a rough check of the accuracy of the data.

The thermal conductivities of consolidated sediments and of basement samples have been measured either by disks in a divided bar apparatus or using the line-source technique on a cut surface of the core. The thermal conductivity of basalts varies little unless they have very high porosity or are highly weathered or altered. There is usually a very serious sampling bias, however. The cracks, fissures, and rubble zones that are not sampled have lower conductivity. If the porosity of the formation can be estimated from downhole logs, porosity-conductivity relations, such as those given by Robertson and Peck (1974), can be used to compute the formation conductivity from the sample data. A temperature correction must be applied in holes with high temperatures.

\section{CONCLUSIONS}

Reliable heat-flow measurements have now (to Site 511) been obtained at over fifty DSDP sites in all of the world oceans except the Arctic. Measurements have been obtained to sub-bottom depths of over 1000 meters, although most measurements were taken in the depth range 75-250 meters. Temperatures have been measured a significant distance into the crust in some eight holes. Thermal conductivity measurements have been made on core samples from most holes in which temperatures have been measured. The measured conductivities of the unconsolidated sediments, corrected for temperature and pressure, should generally be representative of in situ values, unless there is a serious drilling disturbance. There usually is a serious sample bias in basalt basement samples, however, and the large-scale bulk porosity of the formation must be known for reliable estimates to be made of formation conductivity.

The reliable heat-flow values are summarized in Table 1 . All of the measurements attempted are discussed in the Appendix. Here are some general conclusions:

1) Only at about ten sites have three or more reliable downhole temperature measurements been obtained in sediments where the sediment section is thick. These sites show no variations of heat flow with depth within the measurement uncertainties. Thus, the conclusion has been made that measurements to date show no evidence of bottom-water temperature changes of a degree or more over timescales of tens to thousands of years; or of significant heat production within the sediments; or of vertical migration of water through thick sedimentary columns at rates of $10^{-9} \mathrm{~m} \cdot \mathrm{s}^{-1}$ or greater. But at Site 505 , where the sediments are thin, nonlinear gradients suggest that water movement may be occurring or that there is heat production in the sediments. Such water movement may be common in thin deep-sea carbonates that are too unconsolidated to support the drill bit and so have had no temperature measurements.

2) There is good agreement between most of the new deep-sea drill hole heat-flow measurements and conventional shallow-penetration probe measurements made nearby. This further substantiates the conclusion of Erickson et al. (1975) that conventional short-probe measurements generally are not seriously affected by near-surface environmental conditions.

3) Temperatures measured in the igneous crust of deepsea drill holes exhibit a wide range of behavior. In three crustal holes the temperatures, combined with thermal conductivity, indicate the same heat flow as in the overlying sediments (Holes 332B, 334 and lower part of 504B). In one hole the basement heat flow was much higher than in the overlying sediments (Hole 395A, lower part). In two holes into young crust, the deep-basement heat flow was close to the theoretical cooling-lithosphere heat flow (Hole 395A, 7-Ma-old crust; Hole 504B, 6-Ma-old crust), whereas in two others it was much lower (Holes 332 and 334). In five crustal holes the temperatures require strong downward seawater flow into the hole (Hole 

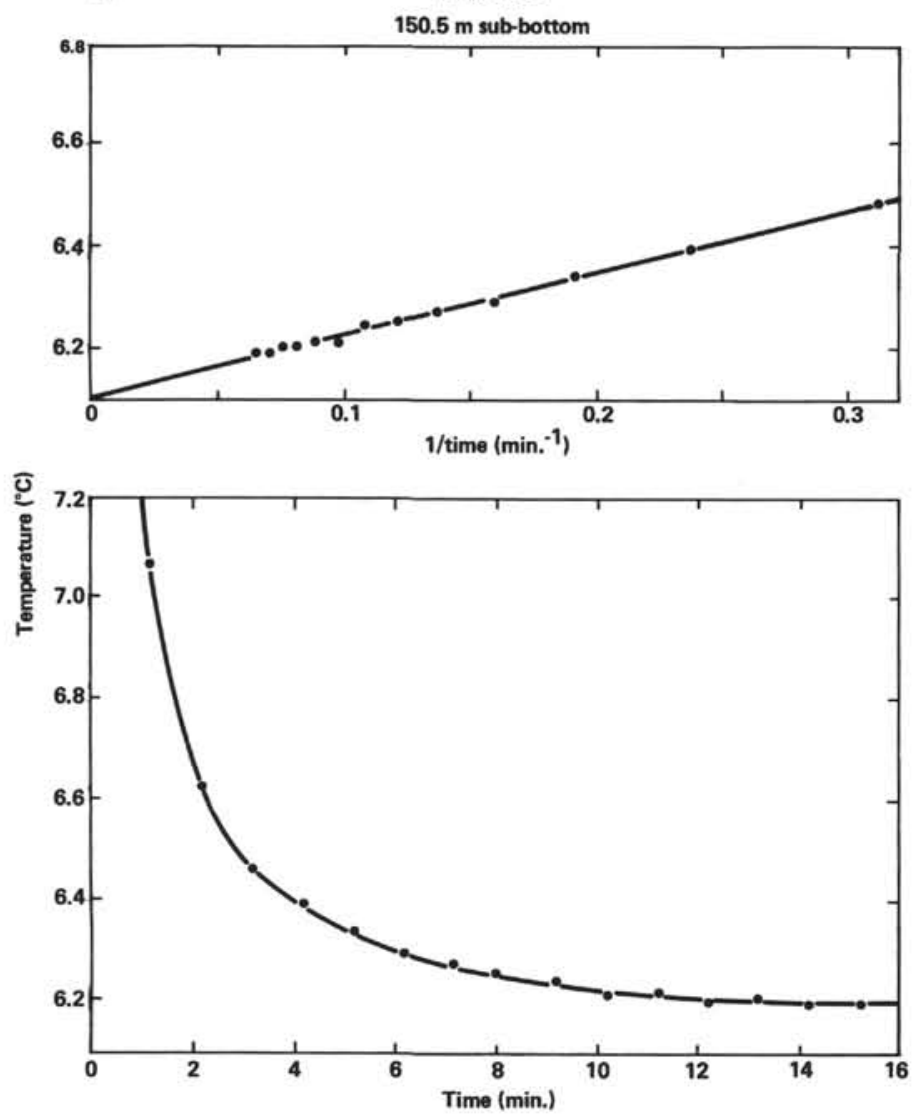

B

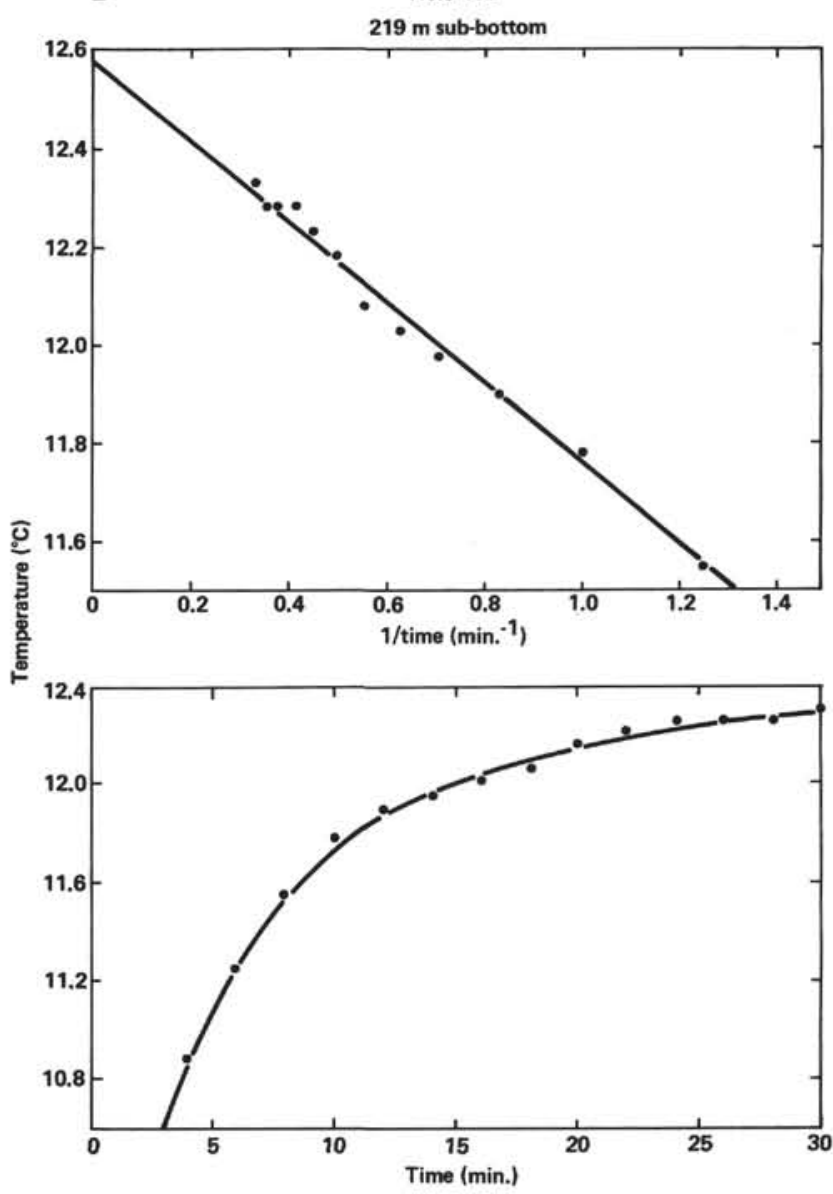

Figure 3. Examples of good time-temperature records made with the probes: one cooling (A) and one warming (B) (Erickson and Hyndman, 1978; Boyce, 1981). The 1/time term (inverse of time) is the long-time approximation of the $F(\alpha, \tau)$ extrapolation to equilibrium.

335; Hole 395A, upper part; Holes 396 and 454A; Hole 504B, upper part), indicating penetration to an underpressured formation. In two of these holes, packer measurements have confirmed subhydrostatic pressures. In one hole (482C) in the Gulf of California, upward flow of water from the hole was inferred from an uncertain seismometer thermometer record. If it does exist, this flow would indicate an overpressure formation. These results all require that, in general, the upper ocean crust be highly permeable. Results from several holes suggest a marked decrease in permeability at a sub-bottom depth of about 500 meters, and it is inferred that, at least in these areas, hydrothermal circulation is concentrated above 500 meters depth in the crust.

\section{ACKNOWLEDGMENTS}

We acknowledge the continuing support of the Deep Sea Drilling Project personnel, both in the development of the heat-flow instruments and measurement techniques and in the shipboard operation. This chapter is Contribution No. 1081 of the Earth Physics Branch.

\section{REFERENCES}

Ade-Hall, J. M., Von Herzen, R. P., and Erickson, A. E., 1977. Inhole temperatures and heat flow, Site 319, Leg 34. In Yeats, R. S., Hart, S. R., et al., Init. Repts. DSDP, 34: Washington (U.S. Govt. Printing Office), 553-556.

Aubouin, J., von Huene, R., et al., 1982. Init. Repts. DSDP, 67: Washington (U.S. Govt. Printing Office).
Becker, K., Langseth, M. G., and Von Herzen, R. P., 1983. Deep crustal geothermal measurements Hole 504B, DSDP Legs 69 and 70. In Cann, J. R., Langseth, M. G., Honnorez, J., Von Herzen, R. P., White, S. M., et al., Init. Repts. DSDP, 69: Washington (U.S. Govt. Printing Office), 223-235.

Becker, K., Langseth, M. G., Von Herzen, R. P., and Anderson, R. N., 1983. Deep crustal geothermal measurements, Hole 504B, Costa Rica Rift. J. Geophys. Res., 88:3447-3457.

Becker, K., and Von Herzen, R. P., 1983. Heat transfer through the sediments of the mounds hydrothermal area, Galapagos spreading centre at $86^{\circ}$ W. J. Geophys. Res., 88:995-1008.

Becker, K., Von Herzen, R. P., and Karato, S., 1983. Geothermal measurements from drilling of sediments near the Galapagos spreading centre, $86^{\circ} \mathrm{W}$, Deep Sea Drilling Project Leg 70. In Honnorez, J., Von Herzen, R. P., et al., Init. Repts. DSDP, 70: Washington (U.S. Govt. Printing Office), 445-458.

Boyce, R. E., 1980. Schlumberger well-log equipment and the Erickson-Von Herzen temperaure probe used during Deep Sea Drilling Project Leg 50. In Lancelot, Y., Winterer, E. L., et al., Init. Repts. DSDP, 50: Washington (U.S. Govt. Printing Office), 849-853, also $151-158$.

1981. Electrical resistivity, sound velocity, thermal conductivity, density-porosity, and temperature, obtained by laboratory techniques and well logs: Site 462 in the Naru Basin of the Pacific Ocean. In Larson, R. L., Schlanger, S. O., et al., Init. Repts. DSDP, 61: Washington (U.S. Govt. Printing Office), 743-761.

Bullard, E. C., 1947. The time necessary for a borehole to attain temperature equlibrium. Mon. Not. R. Astron. Soc., Geophys. Suppl., 5:127-130.

1954. The flow of heat through the floor of the Atlantic Ocean. Proc. R. Soc. London, Ser. A, 222:408-429. 
Bullard, E. C. and Day, A. A., 1961. The flow of heat through the floor of the Atlantic Ocean. Geophys. J., 4:282-292.

Burch, J. K., and Langseth, M. G., 1981. Heat-flow determination in three DSDP boreholes near the Japan Trench. J. Geophys. Res., 86:9411-9419.

Burns, R. E., 1970. Heat flow operations at hole 35.0 and 35.1. In, McManus, D. A., Burns, R. E., et al., Init. Repts. DSDP, 5: Washington (U.S. Govt. Printing Office), 551-554.

Carslaw, H. S., and Jaeger, J. C., 1959. Conduction of Heat in Solids 2nd ed.): London (Oxford University Press).

Carvalho, H. da S., Purwoko, S., Thamrin, M., and Vacquier, V., 1980. Terrestrial heat flow in the Tertiary basin of central Sumatra. Tectonophysics, 69:163-188.

Cooper, L. R., and Jones, C., 1959. The determination of virgin strata temperatures from observations in deep survey boreholes. Geophysical J., 2:116-131.

Curray, J. R., Moore, D. S., et al., 1982. Init. Repts. DSDP, 64: Washington (U.S. Govt. Printing Office).

Duennebier, F., Blackinton, G., and Gieskes, J., 1983. A man-made hot spring on the ocean floor. In Lewis, B. T. R., Robinson, P., et al., Init. Repts. DSDP, 65: Washington (U.S. Govt. Printing Office), 357-359.

Erickson, A. J., 1973. Initial report on downhole temperature and shipboard thermal conductivity measurements, Leg 19. In Init. Repts. DSDP, 19: Washington (U.S. Govt. Printing Office), 643-656.

Erickson, A. J., Avera, W. E., and Byrne, R. E., 1979. Heat flow results, DSDP Leg 48. In Montadert, L., Roberts, D. G., et al., Init. Repts. DSDP, 48: Washington (U.S. Govt. Printing Office), 277-288.

Erickson, A. J., and Hyndman, R. D., 1978. Downhole temperature measurements and thermal conductivities of samples, Site 396, Deep Sea Drilling Project Leg 46. In Dmitriev, L., Heirtzler, J., et al., Init. Repts. DSDP, 46: Washington (U.S. Govt. Printing Office), 389-400.

Erickson, A. J., and Von Herzen, R. P., 1978a. Downhole temperature measurements, DSDP Leg 42A. In Hsu, K. J., Montadert, L., et al., Init. Repts. DSDP, 42, Pt. 1: Washington (U.S. Govt. Printing Office), 857-871.

1978b. Downhole measurements and heat-flow data in the Black Sea, DSDP Leg 42B. In Ross, D. A., Neprochnov, Y. P., et al., Init. Repts. DSDP, 42, Pt. 2: Washington (U.S. Govt. Printing Office), 1085-1103.

Erickson, A. J., Von Herzen, R. P., Sclater, J. G., Girdler, R. W., Marshall, B. V., and Hyndman, R. D., 1975. Geothermal measurements in deep-sea drill holes. J. Geophys. Res., 80:2515-2528.

Fujii, N., 1981. Downhole temperature measurements and heat flow at Hess Rise, Deep Sea Drilling Project Leg 62. In Thiede, J., Vallier, T., et al., Init. Repts. DSDP, 62: Washington (U.S. Govt. Printing Office), 1009-1013.

Girdler, R. W., Erickson, A. J., and Von Herzen, R. P., 1974. Downhole temperature and shipboard thermal conductivity measurements aboard D/V Glomar Challenger, in the Red Sea. In Whitmarsh, R. B., Weser, O. E., et al., Init. Repts. DSDP,23: Washington (U.S. Govt. Printing Office), 879-886.

Horai, K., 1982. Thermal conductivity of sediments and igneous rocks recovered during Deep Sea Drilling Project Leg 60. In Hussong, D. M., Uyeda, S., et al., Init. Repts. DSDP, 60: Washington (U.S. Govt. Printing Office), 807-834.

Hyndman, R. D., Davis, E. E., and Wright, J. A., 1979. The measurement of marine geothermal heat flow by a multipenetration probe with digital acoustic telemetry and in situ thermal conductivity. Mar. Geophys. Res., 4:181-205.

Hyndman, R. D., Erickson, A. J., and Von Herzen, R. P., 1974. Geothermal measurements on DSDP Leg 26. In Davies, T. A., Luyendyk, B. P., et al., Init. Repts. DSDP, 26: Washington (U.S. Govt. Printing Office), 451-463.

Hyndman, R. D., Von Herzen, R. P., Erickson, A. J., and Jolivet, J., 1976. Heat-flow measurements in deep crustal holes on the midAtlantic Ridge. J. Geophys. Res., 81:4053-4060.

1977. Heat flow measurements, DSDP Leg 37. In Aumento, F., Melson, W. G., et al., Init. Repts. DSDP, 37: Washington (U.S. Govt Printing Office), 347-362.
Jaeger, J. C., 1956. Conduction of heat in an infinite region bounded internally by a circular cylinder of a perfect conductor. Aust. J. Phys., 9:167-179. 1961. The effect of the drilling fluid on temperatures measured in boreholes. J. Geophys. Res., 66:563-569. 1965. Application of the theory of heat conduction to geothermal measurements. In Lee, W. H. K. (Ed.), Terrestrial Heat Flow. Am. Geophys. Union Mon. Ser. 8:7-23.

Lachenbruch, A., and Marshall, B. V., 1966. Heat flow through the Arctic Ocean floor. The Canada Basin-Alpha Rise boundary. J. Geophys. Res., 71:1223-1248.

Langseth, M. G., and Burch, J. K., 1980. Geothermal observations on the Japan Trench transect. In Scientific Party, Init. Repts. DSDP, 56, 57, Pt. 2: Washington (U.S. Govt. Printing Office), 1207-1210.

Langseth, M. G., and Ludwig, W. J., 1983. A heat flow measurement on the Falkland plateau. In Ludwig, W. J., Krasheninnikov, V. A., et al., Init. Repts. DSDP, 71: Washington (U.S. Govt. Printing Office), 299-303.

Larson, R., Schlanger, S. O., et al., 1981. Init. Repts. DSDP, 61: Washington (U.S. Govt. Printing Office).

Lewis, B. T. R., 1983. Temperatures, heat flow, and lithospheric cooling at the mouth of the Gulf of California. In Lewis, B. T. R., Robinson, P., et al. Init. Repts. DSDP, 65: Washington (U.S. Govt. Printing Office), 343-355.

Luyendyk, B. P., Cann, J. R., et al., 1979. Init. Repts. DSDP, 49: Washington (U.S. Government Printing Office).

Marshall, B. V., and Erickson, A. J., 1974. Heat flow and thermal conductivity measurements, Leg 25 of Deep Sea Drilling Project. In Simpson, E. S. W., Schlich, R., et al., Init. Repts. DSDP, 25: Washington (U.S. Govt. Printing Office), 349-355.

Ratcliffe, E. H., 1960. The thermal conductivities of ocean sediments. J. Geophys. Res., 65:1535-1541.

Robertson, E. D., and Peck, D. L., 1974. Thermal conductivity of vesicular basalt from Hawaii. J. Geophys. Res., 79:4875-4888.

Sclater, J. G., and Erickson, A. J., 1974. Geothermal measurements on Leg 22 of the D/V Glomar Challenger. In von der Borch, C. C., Sclater, J. G., et al., Init. Repts. of DSDP, 22: Washington (U.S. Govt. Printing Office), 387-396.

Shipley, T. H., and Shepard, L. E., 1982. Temperature data from the Mexico drilling area: Report on logging and inhole temperature experiments. In Watkins, J. S., Moore, J. C., et al., Init. Repts. $D S D P$, 66: Washington (U.S. Govt. Printing Office), 771-774.

ten Brink, U., and Langseth, M. G., 1982. New method for temperature correction in marine boreholes. EOS, Trans. Am. Geophys. Union, 63:434. (Abstract)

Uyeda, S., and Horai, K., 1982. Heat flow measurements, DSDP Leg 60. In Hussong, D. M., Uyeda, S., et al., Init. Repts. DSDP, 60: Washington (U.S. Govt. Printing Office), 789-800.

Von Herzen, R. P., 1973. Geothermal measurements, Leg 21. In Burns, R. E., Andrews, J. E., et al., Init. Repts. DSDP, 21: Washington (U.S. Govt. Printing Office), 443-457.

Von Herzen, R. P., Fiske, R. J., and Sutton, G., 1971. Geothermal measurements on Leg 8. In Tracey, J. I., Jr., Sutton, G. H., et al., Init. Repts. DSDP, 8: Washington (U.S. Govt. Printing Office), 837-849.

Von Herzen, R. P., and Maxwell, A. E., 1959. The measurement of thermal conductivity of deep sea sediments by a needle probe method. J. Geophys. Res., 64:1557-1563.

von Rad, U., Ryan, W. B. F., et al., 1979. Init. Repts. DSDP, 47, Pt. 1: Washington (U.S. Govt. Printing Office).

Watanabe, J., Von Herzen, R. P., and Erickson, A. J., 1975. Geothermal studies, Leg 31, Deep Sea Drilling Project. In Karig, D. E., Ingle, J. C., Jr., et al., Init. Repts. DSDP, 31: Washington (U.S. Govt. Printing Office), 573-576.

Yeats, R. S., Haq, B. U., et al., 1981. Init. Repts. DSDP, 63: Washington (U.S. Govt. Printing Office).

Yokota, I., Kinoshita, K., and Uyeda, S., 1979. New DSDP (Deep Sea Drilling Project) downhole temperature probe utilizing digital selfrecording system with IC RAM elements. Bull. Earthquake Res. Inst., Univ. Tokyo, 54:441-462.

Date of Initial Receipt: July 18, 1983

Date of Acceptance: July 22, 1983 


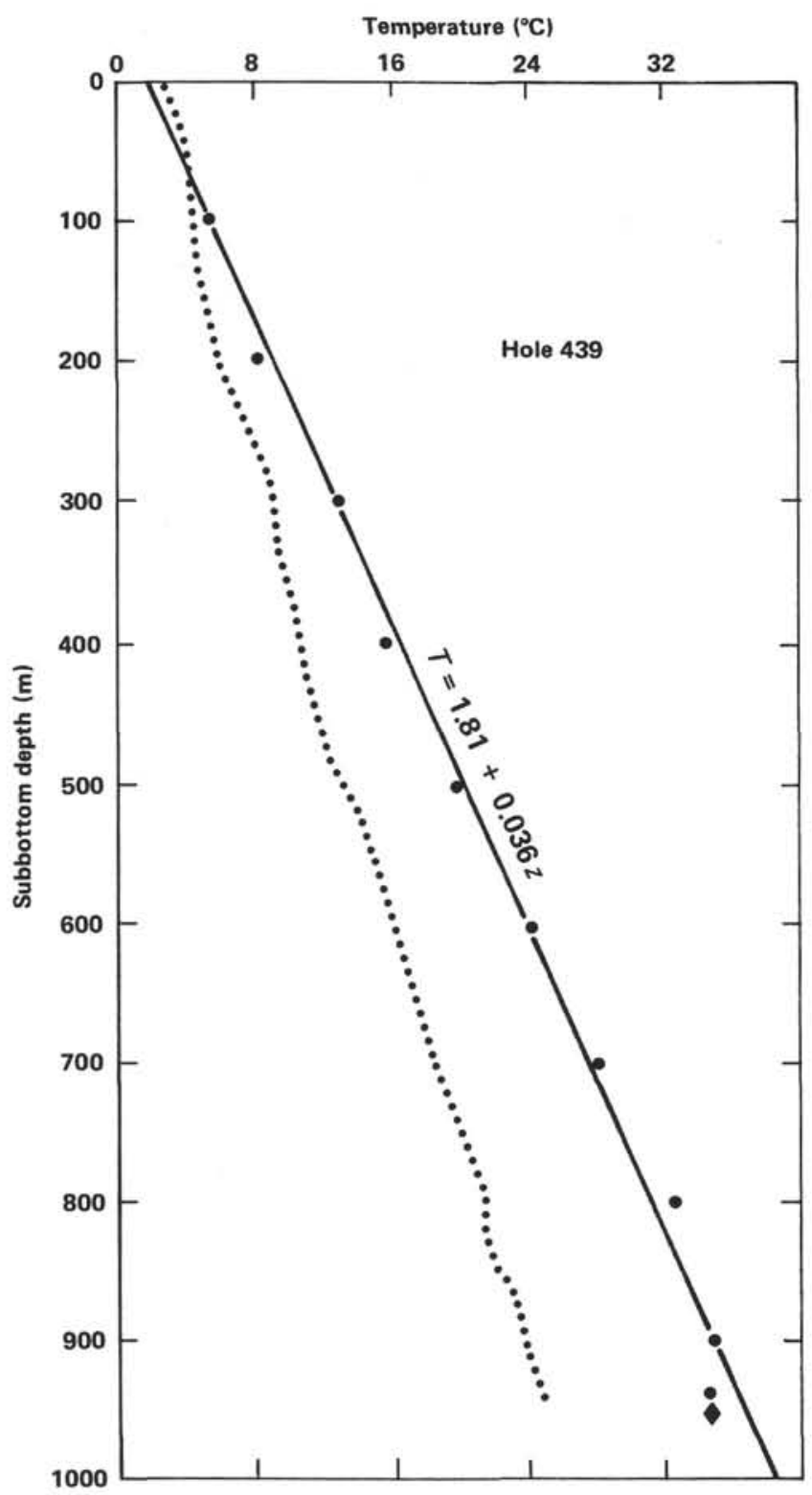

Figure 4. Figure showing the temperature $\log$ (filled circles) and extrapolation to equilibrium (solid line) in a sediment drill hole (Burch and Langseth, 1981). $T=$ temperature, $z=$ depth.

\section{APPENDIX \\ DSDP Heat-Flow Notes ${ }^{1}$}

Leg 5: Hole 35.1, central Pacific (Burns, 1970). Wireline sediment probe as used on pre-Molehole project, needle-probe sediment thermal conductivity started. Sediment temperture records obtained at three depths, but probe probably not held steady for any of the measurements, so results are unreliable.

Leg 8: Holes 71A, 71B, 72B, equatorial Pacific (Von Herzen et al., 1971). Wireline sediment probe, extensive needle-probe conductivity started. Five sediment temperatures recorded, but none have an undisturbed decay of the penetration thermal pulse, so are unreliable. Good downhole temperature logs in three holes give rough gradients; extrapolation to equilibrium using detailed history of drilling-circulation disturbance not yet attempted, but might permit more accurate values.

\footnotetext{
${ }^{1}$ References cited here appear in the references listed for this chapter.
}

Leg 19: Holes 183, 184, 185, Gulf of Alaska, Bering Sea (Erickson, 1973). First operational use of self-contained recording sedimenttemperature probe with latch intended to release at start of coring. Numerous measurements, but all are disturbed-probably from the probe being prematurely released and pushed into the core barrel-and must be considered unreliable.

Leg 21: Holes, 204, 206, 209, 210, southwestern Pacific (Von Herzen, 1973). Numerous sediment temperature measurements; all but two are seriously disturbed-probably by settling in sediments and premature release of latch-and so are unreliable. Hole 206: Short records of warming approach to equilibrium after penetration, for two measurements, gives fair heat-flow estimate.

Leg 22: Holes 213A, 214, 216, 217, Indian Ocean (Sclater and Erickson, 1974). In Holes $213 \mathrm{~A}, 214$, and 216 , use of release latch gave disturbed sediment temperature data that are generally unreliable. Hole 214 temperature-depth profile is consistent. Hole 217: Probe was rigidly attached to core barrel for two measurements; the approach to equilibrium was a warming for both measurements; results are probably reliable, giving heat flow of $70 \mathrm{~mW} \mathrm{~m}^{-2}$.

Leg 23: Holes 225, 227, 228, 229, Red Sea (Girdler et al., 1974). Release latch used with high release pressure; no coring on same operation. Hole 225: One reliable and one unreliable sediment temperature equilibrium. Temperature at 78 meters sub-bottom revised here to $28.1^{\circ} \mathrm{C}$, giving a gradient of $80 \mathrm{mK} \mathrm{m}^{-1}$. Hole 227: Four measurements. Three seem reliable (although all were disturbed a short time after penetration): revised here to $24.1^{\circ} \mathrm{C}$ at 37 meters sub-bottom, $28.0^{\circ} \mathrm{C}$ at 73 meters, and $41.3^{\circ} \mathrm{C}$ at 159 meters subbottom. A nonlinear gradient increasing with depth is suggested if the deepest value is valid. Hole 228: Three temperature measurements made, but none are clearly reliable. If one at 61 meters subbottom, revised here to $26.0^{\circ} \mathrm{C}$, and one at 97 meters sub-bottom, revised here to $41.0^{\circ} \mathrm{C}$, are valid, a gradient increasing with depth is implied. Hole 229: Sediment core temperatures were measured immediately after recovery to obtain very rough in situ estimates. This is an interesting technique, but does not appear to have permitted useful accuracy.

Leg 25: Holes 242, 248, 249, Indian Ocean (Marshall and Erickson, 1974). Probe locked into core barrel. Hole 242: One apparently reliable and one disturbed temperature measurement. Hole 248: One disturbed temperature measurement. Hole 249: One excellent temperature value from cooling of frictional heating caused by penetration gives a reliable heat flow of $42 \mathrm{~mW} \mathrm{~m}^{-2}$.

Leg 26: Holes 251, 251A, 253, 254, 256, 257, Indian Ocean (Hyndman et al., 1974). New downhole temperature-recording package; four lowerings with release latch all gave unreliable disturbed temperature measurements; the remaining eight sediment temperature measurements were made with locked latch, and were generally good. Cylindrical-probe decay function first used for extrapolation to equilibrium. Hole 251: One disturbed, unreliable measurement. Hole 253: Three excellent temperature estimates. Hole 254: One distrubed, unreliable measurement and three reliable temperatures, although two showed disturbance $2 \mathrm{~min}$. after penetration. Hole 256: Short section of undisturbed temperature-time record with warming equilibration gives one probably reliable temperature. Hole 257: One probably reliable temperature measurement from short undisturbed record with warming equilibration.

Leg 31: Holes 297A, 298A, 301, Philippine and Japan seas (Watanabe et al., 1975). Locked-latch sediment temperature probe. Hole 297A: One disturbed, unreliable temperature measurement. Hole 298A: Time-temperature record shows no penetration pulse cooling or heating, but appears to be undisturbed. The probe may not have penetrated undisturbed sediment, but the result is taken to be reliable; conductivity estimated. Hole 301: One excellent temperature measurement at $\mathbf{1 2 6 . 5}$ meters sub-bottom. Thermal conductivity accuracy low because of gas in cores.

Leg 34: Hole 319, East Pacific Rise (Ade-Hall et al., 1977). Two sediment temperature measurements, both seriously disturbed, give unreliable results.

Leg 37: Holes 332A, 332B, 333A, 334, 335, Mid-Atlantic Ridge (Hyndman et al., 1977; Hyndman et al., 1976). Useful sediment temperature measurements obtained in all five holes. The downhole temperature recorder was used to log temperatures in the pipe in the basalt crustal sections of three holes: in Hole 332B after three days, in Holes 334 and 335 a few hours after last circulation. Temperatures extrapolated to equilibrium. Hole 332A: One reliable 
sediment temperature was obtained, although several successive probe-penetration heating pulses were observed. Hole 332B: one excellent and one poor sediment temperature; a good basalt basement temperature log was obtained after re-entry which, after a small correction to equilibrium, gives a low heat flow in agreement with sediment data. Hole 333A: One sediment temperature point with some disturbance. Hole 334: One excellent temperature point, and one where probe apparently did not penetrate undisturbed sediments. A basement temperature log, after large correction to equilibrium, gives temperatures consistent with the sediment value. Hole 335: Three excellent sediment temperature measurements. Logging in basement showed temperatures near to ocean bottomwater temperature, indicating strong downflow through drill hole into crust.

Leg 42A: Holes 372A, 373A, 374, 376, 378, 378 A, Mediterranean Sea (Erickson and Von Herzen, 1978a). Hole 372A: Four excellent sediment temperatures give a very well determined heat flow having no significant variations with depth. Hole 373A: Two excellent temperature measurements, close in depth, give small discrepancy; conductivity poorly determined, so heat-flow rated good. Hole 374: Four excellent sediment temperatures and a fair one give nearly constant heat flow with depth that is very well determined. Hole 376: Five sediment temperatures, but only two are reliable, one at $\mathbf{2 6 . 5}$ meters and one at $\mathbf{1 0 2 . 5}$ meters sub-bottom. They define a nearly linear gradient, revised here to $26^{\circ} \mathrm{C} \mathrm{km}^{-1}$, for a heat flow of $31 \mathrm{~mW} \mathrm{~m}^{-2}$. The other three sediment temperature records, although disturbed, can be interpreted to be consistent with this gradient. Hole 378: Two sediment temperatures, one excellent and one showing an initial slow warming toward equilibrium, then cooling. This latter measurement is interpreted here to imply an in situ temperature of $23.5^{\circ} \mathrm{C}$ at 122 meters sub-bottom, giving a linear gradient and a heat flow of $90 \mathrm{~mW} \mathrm{~m}^{-2}$. Adjacent Hole 378A: One excellent temperature measurement, giving a slightly lower heat flow of $81 \mathrm{~mW} \mathrm{~m}^{-2}$.

Leg 42B: Holes 379, 380, 381, Black Sea (Erickson and Von Herzen, 1978b). Probably the best data so far obtained. Hole 379: Five sediment temperatures give excellent heat-flow estimate. Hole 380: Five sediment temperatures give excellent heat-flow estimate. Hole 381: One temperature that appears to be reliable.

Leg 46: Hole 396B, Mid-Atlantic Ridge (Erickson and Hyndman, 1978). Three sediment measurements, two disturbed and one excellent value from only about one meter above basalt basement. After penetration into basalt, a $\log$ to 25 meters into basement gave temperatures only very slightly above that of the ocean bottom water, indicating strong downflow through the hole into the crust.

Leg 47A: Holes 397, 297A, 398, northeastern Atlantic Margin (von Rad, Ryan et al., 1979). Holes 397 and 397A: two of three sediment temperature measurements appear to give consistent linear data, although there is some uncertainty because the first was disturbed after a few minutes and the second shows no penetration heating or cooling. The one sediment temperature measurement in Hole 398 is not reliable.

Leg 48: Holes 402, 402A, 403, 406, northeastern Atlantic (Erickson et al., 1979). Hole 402: Of three sediment temperature measurements, two appear to be reliable. Hole 402A: One disturbed temperature measurement. Hole 403: Five sediment temperature measurements, none ideal. With reasonable assumptions on the nature of the disturbances, four of the values define a consistent gradient. Hole 406: Of four sediment temperatures, three appear to be valid, giving a very reliable heat flow.

Leg 49: Holes 407 and 408, North Atlantic (Luyendyk, Cann, et al., 1979). Hole 407: Two of three temperatures appear to be reliable. Hole 408: Three temperatures of uncertain reliability give poor heatflow estimate.

Leg 50: Holes 415, 415A, 416A, northeastern Atlantic Margin (Boyce, 1980). Hole 415: One somewhat disturbed sediment temperature measurement and only one conductivity measurement, so heat-flow estimate is unreliable. Hole 416A: A Schlumberger high-resolution temperature $\log$ (HRT) to 459 meters sub-bottom. Value of $30^{\circ} \mathrm{C} /$ $\mathrm{km}$ overall, $23^{\circ} \mathrm{C} / \mathrm{km}$ lower half of measure section, with no correction for drilling disturbance as yet made, so measured gradients are undoubtedly significantly lower than the in situ values.

Legs 56,57: Holes 438A, 439, 440B, Japan Trench (Langseth and Burch, 1980; Burch and Langseth, 1981). High-resolution temperature logs in Holes 438A, 439, and 440; maximum thermometer readings at the bottom of Holes 438A and 439. Careful extrapolation to equilibrium of logs and hole-bottom temperatures, using drilling-circulation history and numerous conductivities, gives reliable heat flows in all holes.

Leg 60: Holes 453, 454A, 456, 456A, 458, 459B, Mariana Basin (Uyeda and Horai, 1981). New sediment temperature recorder and large-diameter probe with a longer time constant led to a heating approach to equilibrium after penetration, and to reduced accuracy. Gearhart-Owen high-resolution temperature log in two holes. QTM conductivity started. Hole 453: The one sediment temperature shows no decay of penetration thermal pulse and shows slight disturbance, so its reliability is not certain. Hole 454A: One inhole probe recording and two complete log profiles give temperatures only slightly above that of ocean bottom water, implying strong downflow of seawater through hole into basalt basement. Hole 456A: Two disturbed sediment temperature records. Hole 458: Two disturbed sediment temperature records. Hole 459B: One probably disturbed sediment temperature record. A series of inhole temperature measurements with recording probe all give temperatures apparently far from equilibrium. Two successive temperature logs permitted extrapolation to equilibrium, but correction is large, so accuracy is low. Estimated heat flow is $30 \mathrm{~mW} \mathrm{~m}^{-2}$.

Leg 61: Holes 462 and 462A, western Pacific (Boyce, 1981; Larson, Schlanger, et al., 1981). Hole 462: Two HRT temperature logs run 12 and 43 hours after last circulation, not yet extrapolated to equilibrium. Near-bottom temperature at 608 meters, sub-bottom, 50 meters into basalt basement, is $22.4^{\circ} \mathrm{C}$, for average gradient of $41^{\circ} \mathrm{C} \mathrm{km}^{-1}$. Estimated effective conductivity here of $1.38 \mathrm{~W} \mathrm{~m}^{-1}$ $\mathrm{K}^{-1}$ gives heat flow of $57 \mathrm{~mW} \mathrm{~m} \mathrm{~m}^{-2}$. Six sediment temperature measurements in Hole $462 \mathrm{~A}$, using large-diameter probe, all show heating approach to equilibrium. Three reasonably reliable sediment temperatures, although not accurately extrapolated to equilibrium, give gradient, estimated here to 219 meters sub-bottom, of $49^{\circ} \mathrm{C} \mathrm{km}^{-1}$. Conductivity, estimated here from Hole 462 data, is $1.0 \mathrm{~W} \mathrm{~m}^{-1} \mathrm{~K}^{-1}$, for heat flow of $49 \mathrm{~mW} \mathrm{~m}^{-2}$.

Leg 62: Holes 465 and 465A, central Pacific (Fujii, 1981). Hole 465: One probably reliable sediment temperature (disturbed after $8 \mathrm{~min}$.) obtained, revised here to $6.0^{\circ} \mathrm{C}$; one unreliable disturbed temperature record in Hole 465A. Hole 465 gradient and QTM average conductivity of $1.39 \mathrm{~W} \mathrm{~m}^{-1} \mathrm{~K}^{-1}$ give heat flow, revised slightly here, of $62 \mathrm{~mW} \mathrm{~m}^{-2}$.

Leg 63: Holes 471, 472, 473, eastern Pacific (Yeats, Haq, et al., 1981). Hole 471: Two sediment temperatures. One may give in situ temperature, revised here to $14.0^{\circ} \mathrm{C}$ from short undisturbed record; the other is unreliable. Two HRT temperature logs, made 18 hours apart, have not been extrapolated to equilibrium. Four successive maximum thermometer hole-bottom temperatures extrapolated to $65-80^{\circ} \mathrm{C}$ range $\left(80^{\circ} \mathrm{C}\right.$ preferred here) at 817 meters sub-bottom. No thermal conductivities measured. Conductivity estimates from porosity suggest very rough heat-flow estimate for site of $125 \mathrm{~mW}$ $\mathrm{m}^{-2}$. Hole 472: One fair sediment temperature, suggesting a high heat flow similar to that in Hole 471. Hole 473: Two of five sediment temperature records appear to give reliable data, with characteristic warming approach to equilibrium. The gradient inferred here is $175-200^{\circ} \mathrm{C} \mathrm{km}^{-1}\left(64^{\circ} \mathrm{C} \mathrm{km}^{-1}\right.$ in Yeats, Haq, et al., 1981). No conductivities were measured, but an estimated average of 0.9 $\mathrm{W} \mathrm{m} \mathrm{m}^{-1} \mathrm{~K}^{-1}$ gives a very rough heat-flow estimate of $160-180 \mathrm{~mW}$ $\mathrm{m}^{-2}$.

Leg 64: Holes 474A, 475, 476, 477, 478, 479, south of Baja California and in Gulf of California (Curray, Moore, et al., 1982). Hole 474A: HRT temperature log not yet extrapolated to equilibrium; hole-bottom temperature suggests heat flow of over $130 \mathrm{~mW} \mathrm{~m}^{-2}$. Hole 475: Three sediment temperature measurements, one probably reliable, which, with needle-probe conductivity, gives heat-flow estimate of $170 \mathrm{~mW} \mathrm{~m}{ }^{-2}$. Hole 476: Two sediment temperture measurements, one probably reliable, which, with measured conductivity, gives rough heat-flow estimate of $108 \mathrm{~mW} \mathrm{~m}^{-2}$. Hole 477: One sediment temperature and one hole-bottom maximum thermometer value suggest very high heat flow of about $800 \mathrm{~mW}$ $\mathrm{m}^{-2}$. Hole 478: One HRT $\log$ and one poor sediment temperature give very rough heat-flow estimate of $150 \mathrm{~mW} \mathrm{~m}^{-2}$. Hole 479: Three sediment temperatures, one very good, which, with conductivity, gives a reliable heat flow of $94 \mathrm{~mW} \mathrm{~m}^{-2}$. Two hole-bottom 
temperatures from HRT logs, extrapolated to equilibrium, give a rough heat-flow estimate of $103 \mathrm{~mW} \mathrm{~m}^{-2}$, in general agreement with probe value.

Leg 65: Holes 482C, 483C, 485, eastern Pacific (Lewis, 1983; Duennebier et al., 1983). Hole 482C: Three sediment temperatures give good heat-flow data with very high value. Downhole seismometer gives even higher temperatures, implying upflow from basalt basement. Hole 483C: One sediment temperature gives fair result. Hole 485: Unreliable temperature log.

Leg 66: Holes 488, 490, 491, 492B, 493B, Mexico margin (Shipley and Shephard, 1982). Hole 488: Two sediment temperature records that both appear to be disturbed; one suggests $9^{\circ} \mathrm{C}$ at 162.5 meters subbottom, for a gradient of $40^{\circ} \mathrm{C} \mathrm{km}-1$. Hole 490 : Three sediment temperature records. One at 94.5 meters sub-bottom may give in situ temperature, revised here to about $8^{\circ} \mathrm{C}$, for a gradient of about $50^{\circ} \mathrm{C} \mathrm{km}^{-1}$ and a heat flow of $60 \mathrm{~mW} \mathrm{~m}^{-2}$. Hole 491: One disturbed record suggesting a temperature of $14.5^{\circ} \mathrm{C}$ at $304.5 \mathrm{me}-$ ters sub-bottom, for a gradient of $40^{\circ} \mathrm{C} \mathrm{km}^{-1}$. Holes 492B and 493B: Temperatures logged shortly after last circulation; extrapolation to equilibrium has not been attempted, so results are not useful. Regional heat flow probably $50-60 \mathrm{~mW} \mathrm{~m}^{-2}$.

Leg 67: Hole 494A, Central America margin (Aubouin, von Heune, et al., 1982). Temperature from emplaced seismometer package $8.5^{\circ} \mathrm{C}$ at 297 meters sub-bottom, for rough estimated gradient of $20^{\circ} \mathrm{C} \mathrm{km}^{-1}$, implying a low heat flow.
Leg 69A: Holes 501, 504A, 504B, 504C, 505, eastern Pacific (Becker, Langseth, and Von Herzen, 1983; Becker, Langseth, Von Herzen, and Anderson, 1983). Hole 501: One good sediment temperature; reliable heat flow. Hole 504A: Two sediment temperatures and an HRT log give excellent heat-flow estimate. Hole 504B: Two successive HRT logs, corrected to equilibrium, give good data in basalt basement, suggesting seawater downflow into upper basement and conductive regime near bottom of hole. Hole 504C: Three sediment temperatures give excellent heat-flow estimate. Hole 505: Four sediment temperatures give nonlinear gradient estimate.

Leg 70: Holes 506E, 506F, 507A, 507E, 507G, 507I, 508A, 508D, 508E, 509C, 509D, 510, Galapagos, eastern Pacific (Becker, Von Herzen, and Karato, 1983; Becker and Von Herzen, 1983). Detailed series of sediment temperature measurements in hydrothermal mounds area. Many of the gradients are nonlinear, indicating advective heat transport through thin sediments. All heat-flux estimates are very high, up to $620 \mathrm{~mW} \mathrm{~m}^{-2}$. Conductive heat-flux estimates were made in 506E, 507F, 507A, 507E, 509D, but all are of only fair reliability because of the very shallow depth of penetration into the bottom (maximum 26 meters).

Leg 71: Hole 511, Falkland Plateau, S. Atlantic (Langseth and Ludwig, 1983). Two excellent measurements to $113 \mathrm{~m}$ and good conductivity measurements give an excellent heat flow value. 